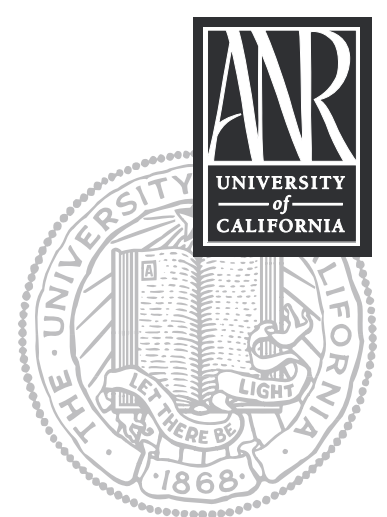

UNIVERSITY OF CALIFORNIA

Division of Agriculture and Natural Resources http://anrcatalog.ucdavis.edu

This document briefly describes opportunities for dairy nutritionists to assist their clients in meeting water quality regulatory needs.

\title{
Dairy Nutritionists' Roles in Nutrient Use: \\ Recommendations for Feed Nutrient Records Analyses
}

DEANNE MEYER, Livestock Waste Management Specialist, Department of Animal Science, University of California, Davis; PETER ROBINSON, Dairy Cattle Nutritionist, University of California, Davis

\section{INTRODUCTION}

Dairy nutritionists have a critical role in ensuring the viability of California dairies. In particular, as dairy operators are obligated to provide detailed information on animal and facility management practices to local, regional, and state regulatory agencies, nutritionists will need to identify vital information for nutrient management. Nutritionists will also need to formulate diets that reduce the impact of dairy cows on the environment.

Nutritionists have traditionally developed diets that meet or exceed minimum concentrations of nutrients for animal health and are cost effective. Standard feed nutrient recommendations for dairy cows are readily available (NRC 1989 and 2001), and numerous software programs are available for formulating diets with balanced nutrients. However, few of the software programs identify maximum nutrient concentrations or impose constraints to prevent overfeeding of most nutrients.

Since feed management practices affect the impact of dairy cows on the environment, nutritionists must consider nutrient excretion when formulating diets. They will increasingly need to use software for calculating whole-farm nutrient balances for key macronutrients such as nitrogen $(\mathrm{N})$ and phosphorus $(\mathrm{P})$. Tracking other nutrients may also be important, especially in areas where feeds are imported and evaporation exceeds rainfall.

\section{NUTRIENTS IN FEED AND PRODUCTS}

Herd characteristics affect the efficiency with which feed nutrients are converted to animal products. At dairies, the incorporation of feed nutrients into animal products is highest for lactating cows and lowest for nonlactating animals. Since each dairy has its own proportions of cattle at various stages of growth and production, the maximum potential efficiency of nutrient conversion will vary by facility. Changing the herd composition may be one way to reduce nutrient excretion at a dairy.

Management practices also affect feeding efficiency at dairies. Feed storage and mixing methods, as well as feed quality and frequency of feeding, contribute to the efficiency by which feed nutrients brought onto the dairy production facility are actually used by the animals. Because feed processing alters the nutrient availability to animals, efficient processing practices should be employed. Ensiling should encourage rapid fermentation (e.g., fill fast, pack densely, cover immediately) by using practices that help minimize protein degradation to nonprotein nitrogen compounds.

Feed ingredients or ingredient form can affect manure composition (see Powers et al. 2001). Regular analysis of by-product feeds (especially wet feeds) must occur to account for nutrient (moisture, protein. and phosphorus) variability when diets are 
formulated (see DePeters et al. 2000). Critical analysis of the inclusion of buffers, salts, trace minerals, and other feed supplements and its impact on manure salt content is important to minimize excretion of salts in manure.

Shrink, or feed lost through processing or relocation at the facility, increases feed losses and thereby decreases nutrient efficiency at the farm level. Also, when feeding frequency and amount is not matched to animal consumption, uneaten feed decreases nutrient efficiency. Poor-quality feed can also result in inefficient nutrient use.

\section{Production Facility Nutrient Balance Analysis}

Production facility nutrient balance analysis evaluates the relationship between nutrients entering a dairy and those exiting the dairy, primarily in milk (fig. 1). The facility nutrient balance provides a broad overview of nutrients such as nitrogen, phosphorus, and potassium entering and exiting the production area at a dairy. Changing the feed input or the animal inventory changes the nutrient balance. Changing bedding materials may also affect the balance of some nutrients.

\section{WATER CONTRIBUTION TO THE WASTE STREAM}

Drinking water and washwater may contribute significant amounts of nutrients to dairy wastewater. If water supplies have high levels of sodium $(\mathrm{Na})$ and chlorine $(\mathrm{Cl})$, the water may contribute more sodium and chlorine to manure than does feed. Increasing dietary chlorine to offset elevated potassium and sodium to gain electrical neutrality results in increased chlorine excretion. There should be opportunities to decrease salt in the diet.

In areas where salt management is a concern, it is important to evaluate water use and the contribution of water used for drinking, udder hygiene, and cow cooling to the nutrients and other salts in the manure stream. Circumstances may exist where reduced water use is needed to decrease salt load in the manure stream. Any alterations to water use must consider the impact on animal health and well being as well as milk quality. Additionally, it is important to understand ramifications of water use changes on manure stream utilization.

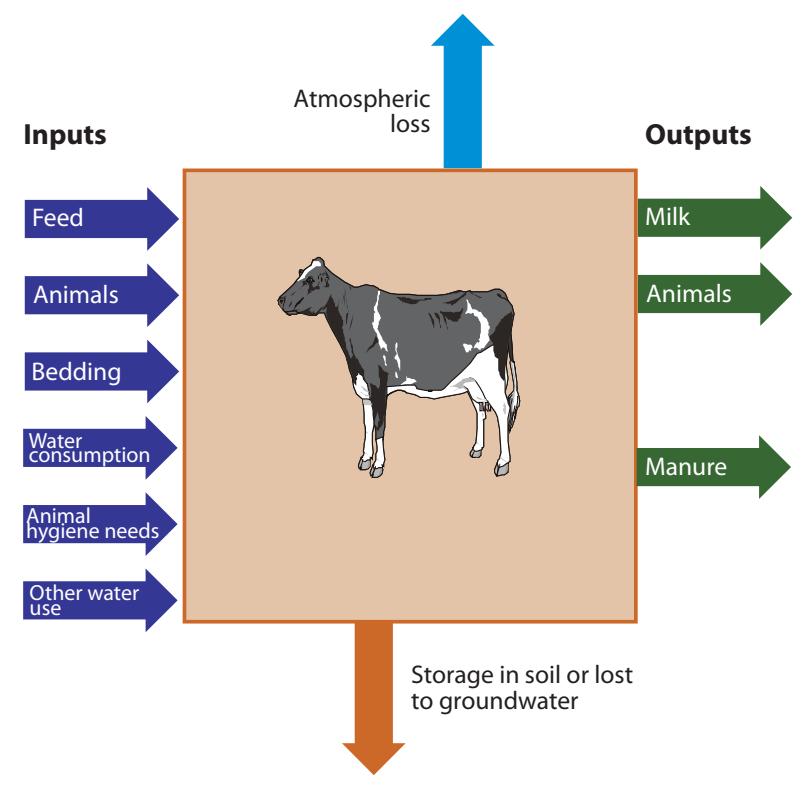

Figure 1. Production facility nutrient balance parameters.

\section{NUTRIENT CONVERSION EFFICIENCY}

Key goals of nutrient management are to maximize animal use (i.e., incorporation) of feed nutrients, minimize nutrient losses, and accurately evaluate nutrient outputs. The efficiency of the incorporation of selected nutrients at several commercial dairies in California is presented in table 1 . These data are provided for comparison purposes only and are not intended to represent maximum or minimum values. Most of the differences in nitrogen conversion between the dairies are due to animal population differences (e.g., nonlactating versus lactating cattle).

Incorporation of sodium and chlorine into animal products varied widely and depended on the methods of supplementing salts and on the feed supplements used at the facility. The highest-efficiency herd for sodium incorporation (Herd 1 in table 1 ) fed salt in the block form and not in the total mixed ration. Also, this herd did feed sodium bicarbonate. 
Table 1. Efficiency of incorporation of nutrients into animal product

\begin{tabular}{|l|l|l|l|l|l|l|l|l|}
\hline & \multicolumn{7}{|c|}{ Grams incorporated $\div$ grams consumed } \\
\hline Herd & $\mathbf{N}$ & $\mathbf{C a}$ & $\mathbf{P}$ & $\mathbf{K}$ & $\mathbf{M g}$ & $\mathbf{N a}$ & $\mathrm{Cl}$ \\
\hline 1 & 0.18 & 0.32 & 0.21 & 0.14 & 0.04 & 0.55 & 0.38 \\
\hline 2 & 0.27 & 0.15 & 0.29 & 0.10 & 0.03 & 0.06 & 0.14 \\
\hline 3 & 0.26 & 0.25 & 0.38 & 0.11 & 0.05 & 0.39 & 0.42 \\
\hline 4 & 0.21 & 0.15 & 0.29 & 0.10 & 0.04 & 0.09 & 0.13 \\
\hline 5 & 0.16 & 0.14 & 0.26 & 0.09 & 0.02 & 0.12 & 0.19 \\
\hline 6 & 0.21 & 0.14 & 0.22 & 0.10 & 0.03 & 0.11 & 0.18 \\
\hline 7 & 0.27 & 0.20 & 0.33 & 0.07 & 0.04 & 0.13 & 0.30 \\
\hline
\end{tabular}

\section{WHY ESTIMATE NUTRIENT EFFICIENCY?}

Evaluating nutrient efficiency can help in estimating the quantity of nutrients excreted and potentially available for application to cropland. For example, for each 1,000 pounds of phosphorus imported to Dairy 1, about 210 pounds of phosphorus were exported and 790 pounds remained in the manure. Similar calculations can be made for other nutrients; however, because some of the nitrogen excreted by the cattle will be lost to the atmosphere, primarily as ammonia, the estimation for nitrogen is more complicated.

Estimates of excreted nutrients and information on nutrients needed for crops can be used to evaluate the amount of land needed for manure nutrient application. The best estimates of excreted nutrients are based on data that accurately reflect the nutrients entering a dairy and those exiting the dairy. Such estimates are more precise than estimates that use book values to estimate pounds of phosphorus or nitrogen excreted per head.

\section{CONTRIBUTION OF FEED CATEGORIES}

The contribution of specific feed categories to total nutrient imports may be evaluated to help dairy operators identify how nutrient imports can be reduced. An example of feed category contributions to total feed nutrients for a dairy facility is presented in table 2.

When any individual category of feed represents more than 25 percent of any nutrient used in ration formulations, sampling and analyzing that feed is critical. In the example provided, it is very important to analyze forages to determine nitrogen, phosphorus, potassium, calcium, magnesium, sodium, and chlorine levels because forages represent more than 25 percent of each of these nutrients for the dairy herd. The critical control point for sodium and chlorine is often in the category of additional feed supplements. Attention to feed supplements is necessary if the sodium content of manure is a concern.

\section{PROVIDING TECHNICAL INFORMATION TO REGULATORY AGENCIES}

Regulatory agencies may require dairy operators to document mass balance approaches to estimate nutrients remaining on farm in manure streams. A consulting nutritionist must be familiar with such record-keeping activities and be able to provide reports estimating conservative values for nutrients excreted and not removed from the facility.

\section{FEED MANAGEMENT PRACTICES}

Many practices can be used by a dairy nutritionist or operator to minimize excretion and accumulation of excess nutrients at the dairy. 
Table 2. Contribution of feed categories to total nutrient inputs

\begin{tabular}{|l|c|c|c|c|c|c|c|}
\hline & \multicolumn{7}{|c|}{ Percent of total intake of nutrient from feed } \\
\hline Feed category & $\mathbf{N}$ & $\mathbf{C a}$ & $\mathbf{P}$ & $\mathbf{K}$ & $\mathbf{M g}$ & $\mathbf{N a}$ & $\mathbf{C l}$ \\
\hline forages & 68.03 & 75.17 & 50.18 & 62.41 & 60.75 & 26.12 & 69.51 \\
\hline plant by-products & 3.89 & 4.64 & 3.05 & 14.75 & 3.61 & 2.39 & 0.70 \\
\hline grains & 8.52 & 0.65 & 14.38 & 3.88 & 4.35 & 1.37 & 3.84 \\
\hline protein meals & 11.31 & 1.39 & 8.41 & 5.51 & 2.62 & 0.39 & 0.59 \\
\hline whole seeds & 6.08 & 2.24 & 9.53 & 6.43 & 5.11 & 0.89 & 1.50 \\
\hline miscellaneous & 0.15 & 0.01 & 0.13 & 0.04 & 0.03 & 0.25 & 0.93 \\
\hline minerals and vitamins & 0.00 & 0.42 & 0.00 & 0.00 & 0.00 & 11.55 & 13.50 \\
\hline additional supplements & 0.12 & 14.57 & 12.52 & 1.59 & 22.65 & 56.39 & 5.51 \\
\hline bedding & 1.91 & 0.92 & 1.79 & 5.37 & 0.87 & 0.63 & 3.94 \\
\hline
\end{tabular}

- Frequently check that the feedstuffs needed for the formulated diets are present in sufficient quantity.

- Analyze incoming feeds, especially forages and wet ingredients, for key nutrients (N, $\mathrm{P}, \mathrm{K}, \mathrm{Ca}, \mathrm{Mg}, \mathrm{Na}$, and $\mathrm{Cl}$ ), and use that information in diet formulation.

- Create a historical library of analyses of feed and manure.

- Reevaluate the use of distiller's grains when they are included in diets at higher than historic amounts. Sample frequently and modify inclusion based on protein and moisture content.

- Determine contribution to manure salt load when dietary buffers are included in rations.

- Evaluate the use of feed supplements and their impact on the nutrient content of manure; seasonally reevaluate inclusion of all dietary supplements.

- Monitor feed management to minimize waste and spoiled feeds.

- Evaluate salt levels in feeds and avoid using feeds that contribute excessive salts or undesired salts to manure.

- Determine the contribution to manure salt load when free choice or block salt is included in total mixed rations.

- Minimize water use if salts are elevated in water and a concern in manure.

\section{REFERENCES}

DePeters, E. J, J. G. Fadel, M. J. Arana, N. Ohanesian, M. A. Etchebarne, C. A. Hamilton, R. G. Hinders, M. D. Maloney, C. A. Old, T. J. Riordan, H. Perez-Monti, and J. W. Pareas. 2000. Variability in the chemical composition of seventeen selected by-product feedstuffs used by the California dairy industry. Professional Animal Scientist 16:69-99.

NRC (National Research Council). 1989. Nutrient requirements of dairy cattle. 6th rev. ed. Washington, DC: National Academy Press.

- 2001. Nutrient requirements of dairy cattle. 7th ed. Washington, DC: National Academy Press.

Powers, W. J., and H. H. Van Horn. 2001. Nutritional implications for manure nutrient management planning. Applied Engineering in Agriculture 17:27-39. 


\section{FOR FURTHER INFORMATION}

A companion publication is available for dairy nutritionists: Use of Feed Inventory

Records to Reduce Nutrient Loading at Dairy Operations (ANR Publication 8277, http://anrcatalog.ucdavis.edu/pdf/8277.pdf).

To order or obtain ANR publications and other products, visit the ANR Communication Services online catalog at http://anrcatalog.ucdavis.edu or phone 1-800-994-8849. You can also place orders by mail or FAX, or request a printed catalog of our products from

University of California

Agriculture and Natural Resources

Communication Services

6701 San Pablo Avenue, 2nd Floor

Oakland, California 94608-1239

Telephone: (800) 994-8849 or (510) 642-2431

FAX: (510) 643-5470

E-mail inquiries: danrcs@ucdavis.edu

This publication has been anonymously peer reviewed for technical accuracy by University of California scientists and other qualified professionals. This review process was managed by the ANR Associate Editor for Animal, Avian, and Aquaculture Sciences.

Funding for this project has been provided in part by the U.S. Environmental Protection Agency (USEPA) pursuant to Assistance Agreement No. C9-98998901-0 and any amendments thereto which has been awarded to the State Water Resources control Board (SWRCB) for the implementation of California's Nonpoint Source Pollution Control Program. The contents of this document do not necessarily reflect the views and policies of the USEPA or the SWRCB, nor does mention of trade names or commercial products constitute endorsement or recommendation for use.

Publication 8278

ISBN-13:978-1-60107-515-4

C2007 The Regents of the University of California

Division of Agriculture and Natural Resources

All rights reserved.

No part of this publication may be reproduced, stored in a retrieval system, or transmitted, in any form or by any means, electronic, mechanical, photocopying, recording, or otherwise, without the written permission of the publisher and the authors.

The University of California prohibits discrimination or harassment of any person on the basis of race, color, national origin, religion, sex, gender identity, pregnancy (including childbirth, and medical conditions related to pregnancy or childbirth), physical or mental disability, medical condition (cancer-related or genetic characteristics), ancestry, marital status, age, sexual orientation, citizenship, or status as a covered veteran (covered veterans are special disabled veterans, recently separated veterans, Vietnam era veterans, or any other veterans who served on active duty during a war or in a campaign or expedition for which a campaign badge has been authorized) in any of its programs or activities. University policy is intended to be consistent with the provisions of applicable State and Federal laws.

Inquiries regarding the University's nondiscrimination policies may be directed to the Affirmative Action/Staff Personnel Services Director, University of California, Agriculture and Natural Resources, 1111 Franklin Street, $6^{\text {th }}$ Floor, Oakland, CA 94607-5201, (510) 987-0096. For information about ordering this publication, telephone 1-800-994-8849.

pr-10/07-SB/CM 